\title{
Child Poverty and Emerging Children's Rights Discourse in Early Republican Turkey
}

\author{
Kathryn Libal
}

[W] e are poor, very poor. We have hundreds and thousands of children who are hungry and neglected vagrants living on the streets. The majority of these children die and many of [those who live] are not being brought up properly. We must know that these neglected and dying children are the pure blood that flows in our veins. If we cannot save them from poverty and death, we will never be able to feel the real joy of living and we will not be able to say that we did our duty for the future. In our country the child question is not so simple that one or a few organizations will be able to tackle it. The state should take this as one of its most important tasks. The state is the expression of the society's will and our society is one that will depend on being led by the hand. ${ }^{1}$

\section{Introduction}

The unnamed author of the above column published in 1935 in Turkey's leading newspaper, Cumhuriyet, encapsulates a dominant theme in newspaper and serial publications in the early Turkish Republic. Child poverty and dislocation that resulted from the aftermath of more than a decade of war, followed by the onset of economic recession, troubled social reformers who worked to establish a strong Turkish nation-state. While such reformers espoused political perspectives ranging from liberalism to socialism, they shared a common concern that the state must fully embrace tackling child poverty and attendant social problems - and, for most, the state had an obligation to secure child welfare through the creation of an expansive program of social protection. Such programs were being introduced throughout Europe and the United States during this era and Turkish reformers were fully aware that addressing

1 "Biz Bize Çocuklarımız," Cumhuriyet, August 28, 1935, 5. Quote initially published in translation in Kathryn Libal, "The Children's Protection Society: Nationalizing Child Welfare in Early Republican Turkey," New Perspectives on Turkey 23, 2003, 53-78.

(C) KATHRYN LIBAL, 2016 | DOI 10.1163/9789004305809_004

This is an open access title distributed under the terms of the Creative Commons Attribution-

Noncommercial 3.0 Unported (CC-BY-NC 3.0) License. 
child welfare systematically through state-directed and funded efforts signified a 'modern' approach to ending child poverty.

Evidence of this desire to tackle child poverty as one of the most pressing social problems abounds across print media in the 1930s, ranging from progovernment newspapers and serial publications to the independent, critical press. Yet by the mid-1930s, such discourse contradicted a key ideological stance of the Republican People's Party platform: a principle asserting populism and denying the existence of social classes in Turkey. ${ }^{2}$ In this chapter I show how social reformers-both those who sought to work within the ruling regime and those who opposed the RPP's leadership—endeavored to highlight this contradiction in their advocacy for greater state investment in child welfare programs. The chapter is organized in three parts. First, I outline the discursive parameters of the debate on the 'child question,' focusing especially on social reformers' desire to promote rapid population growth and combat infant and child mortality as a matter of national urgency. Then I illustrate several modes of writing, and particular children's rights claims, made by journalists and social commentators, including leftist journalists and writers such as Sabiha Zekeriya Sertel and Suad Derviş. Sertel and Derviş sought to underscore that governmental support for ideologies of 'populism' and 'classlessness' meant little in the face of failures to develop comprehensive social welfare and labor supports. Finally, in a related vein I show how satire in the print media was used to highlight the persistence of social inequality and class, especially in urban areas such as Istanbul. Throughout I point to the deployment of contrasting figures of the poor child and the wealthy child to draw attention to the reality of social hierarchy and difference in Turkish society. Precisely because of the increasing sentimentalization of childhood and the use of children in advertising and popular culture to depict a modern Turkish domesticity, reformers prodded the state and political elites using the specter of unequal childhoods to mobilize for additional resources and programs.

This chapter develops aspects of earlier scholarship in which I examined the social construction of the 'child question' that surfaced so often in public and governmental debate in the early Turkish Republic. ${ }^{3}$ The work sheds light

2 In May $193^{1}$ the Third Party Congress adopted six core principles as undergirding Kemalism (Ataturkism). These included: Republicanism, nationalism, populism, statism, secularism and revolutionism/reformism. See Feroz Ahmad, The Making of Modern Turkey (London: Routledge, 1993), 63.

3 Kathryn Libal, “The Child Question': The Politics of Child Welfare in Early Republican Turkey," in Mine Ener, Michael Bonner and Amy Singer (eds) Poverty and Charity in Middle Eastern Contexts (Albany: State University of New York Press, 2003), 255-272. 
on the intersection of public discourses of nationhood and childhood in the construction of the Turkish nation-state. In an era of competitive nationhood, children of the early Republic were treated as a national asset, a product to be cultivated, nurtured and trained. As Dr Kutsi Halkacı put it in the first line of his tract on child protection: "The work of child protection is a national prin-

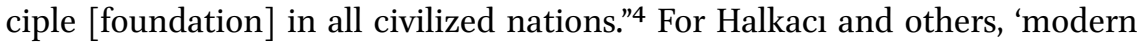
techniques' [modern teknik] in child protection were regarded as inextricably tied to population growth and the 'politics of health' [sihhat siyasası], which included the need to educate women on health in pregnancy and child rearing, especially in the months after a baby was born.

In official ideology children were considered a resource of the nationstate- a generation of future citizens who would be entrusted with protecting the nation-state, just as they too had been protected when young. ${ }^{5}$ As Alemdaroğlu notes, these projects emerged in the context of eugenics discourses operating throughout Europe and other parts of the world in the 1930s, and as a progressive current "went hand in hand with social hygiene, pro-natalist and child-care policies." ${ }^{\prime}$ Yet this ideological vision of childhood as constituting the new nation-state, promoted so actively by publicists and politicians of the day, was in contrast to the daily lives of most children and thus the dominant narrative on state concern for childhood was a ready target for critique.

\section{Rhetorics and Realities of Nation Building}

Political leaders and social reformers of the new Republic grappled with questions of post-war reconstruction, the recrafting of nation-state bureaucratic structures and processes, and the transformation of a beleaguered Ottoman citizenry into that of a Turkish national one. As such, they had to deal with elite and popular concerns with material and moral aspects of basic subsistence and the social construction of stratification and socio-economic

4 This was one in a series of Istanbul cPs publications disseminated for free. Kutsi Halkacı, Çocukları Esirgemenin Modern Tekniği [Modern Techniques in the Protection of Children]. Türkiye Çocuk Esirgeme Kurumu İstanbul Merkez Hey'eti Neşriyatı, Sayı 3 (İstanbul: Millî Mecmua Basım Evi, 1937), 3.

5 Kathryn Libal, "The Robust Child: Discourses on Childhood and Modernity in Early Republican Turkey," in Daniel T. Cook (ed.) Symbolic Childhood (New York: Peter Lang, 2002), 109-130.

6 Ayça Alemdaroğlu, "Politics of the Body and Eugenic Discourse in Early Republican Turkey," Body and Society, 11 (3), 2005, 68. 
inequality in the new Republic. In recent scholarship, Yasemin Gencer notes the co-construction of childhood and nationhood in 1920s Republican Turkey:

The child's liminal status as a link between past ancestral achievements and future transformation was exploited to present nationalist belief in the continuity and persistence of the solidary nation. ${ }^{7}$

Moreover, according to Gencer, the image of the child dominated in cartoons of the early Republic, simultaneously representing "the young Republic, the innocent nation, or future generations of Turkish people." ${ }^{8}$ This discursive preoccupation with the nation imagined through child-as-future provided an opportunity for those seeking governmental support for child welfare and for the institutionalization of efforts that had been unfolding to secure child wellbeing since the late Ottoman Empire.

In the 1920 and 1930 s children symbolized progress towards nationhood and realizing goals of modernization. In their figures resided the promise of a vital national future. Children signified the possibility to create modern Turkish subjects and for many social reformers the possibility to transcend the divide between rich and poor. By the time Turkey's independence was declared in 1923, attitudes and beliefs about children and childhood had begun to shift under the influence of modernist and nationalist currents of the late Ottoman period. The child was portrayed as resource, reservoir and source of hope for the nation-state. ${ }^{9}$ At the same time, because of the prevalence of poor children displaced from homes and living and working on the streets of urban centers like Istanbul, the child also signified potential danger or futures not attained. Social reformers troubled over how poor children might be recovered and included alongside the thousands of Turkish children beginning to attend elementary school.

The roots of sentimentalizing the plight of poor children and 'child-saving' efforts predated the early Republic, as a number of other scholars have shown in their studies of the late Ottoman period..$^{10}$ This concern intensified in the

$7 \quad$ Yasemin Gencer, "We Are Family: The Child and Modern Nationhood in Early Turkish Republican Cartoons (1923-1928)," Comparative Studies of South Asia, Africa and the Middle East 32 (2), 2012, 295.

8 Gencer, "We Are Family," 296.

9 Libal, "The Child Question"; Libal, "The Robust Child"; Hale Yllmaz, Becoming Turkish: Nationalist Reforms and Cultural Negotiations in Early Republican Turkey (1923-1945) (Syracuse, NY: Syracuse University Press, 2013).

$10 \quad$ Nadir Özbek, "The Politics of Welfare, Philanthropy, Voluntarism and Legitimacy in the Ottoman Empire, 1876-1918" (Unpublished PhD thesis, State University of New York, 
1920 and 1930s, demonstrated by the predominance of attention given to the 'child question' within newspapers, popular magazines and radio, scholarly study and analysis, education, private and public philanthropic activities, and regulation of child health and welfare at the official level within municipalities and the state. Evidence of such concern can also be found in official records between parliamentarians and high-ranking officials within Republican government. As one illustration of the extent to which state actors themselves assumed governmental engagement in child welfare, we can consider questions directed by Naci Paşa, a parliamentarian from Cebeli Bereket (later renamed Osmaniye) to the Minister of Interior, Şükrü Kaya, concerning the conditions facing children in Ankara in $1929 .{ }^{11}$ Noting with dismay the large numbers of girls and boys of varying ages on the streets of Ankara and other cities, Naci Paşa asked how the Minister of Interior planned to strengthen social welfare supports for children. Of particular concern to the parliamentarian was the failure to impart morals and education to children who lived and worked on the streets, and the likelihood such children could be exploited for any number of "unclean" forms of work.

It is in this context of heightened political interest in child welfare and nation formation that I consider the emerging public discourse that children had a right to well-being, security and protection by the state. Social reformers sought to highlight, define and create modern social institutions and mechanisms to address child poverty and related social problems. As Dr Halkacı asserted in his 1937 text on Modern Techniques of Child Welfare:

Binghamton, 2001)—see also revised version in Turkish, Nadir Özbek, Osmanlı Imparatorluğu'nda Sosyal Devlet, Siyaset, İktidar ve Meşrutiyet, 1876-1914 (İstanbul: İletişim Yayınları, 2002); Nadir Özbek, "The Politics of Modern Welfare Institutions in the Late Ottoman Empire (1876-1909)," International Journal of Turcologia 3 (5), 2008, 42-62; Nazan Maksudyan, "Hearing the Voiceless-Seeing the Invisible: Orphans and Destitute Children as Actors of Social, Economic, and Political History in the Late Ottoman Empire" (Unpublished PhD thesis, Sabancı University, 2008); Nazan Maksudyan, "Modernization of Welfare or Further Deprivation? State Provisions for Foundlings in the Late Ottoman Empire," Journal of the History of Childhood and Youth 2 (3), 2009, 361-392; Nazan Maksudyan, "Orphans, Cities, and the State: Vocational Orphanages (Islahhanes) and Reform in the Late Ottoman Urban Space," International Journal of Middle East Studies, 43, 2011, 493-511; Nazan Maksudyan, Orphans and Destitute Children in the Late Ottoman Empire (Syracuse, NY: University of Syracuse Press, 2014).

11 Correspondence from Cebeli Bereket representative Naci Paşa Hazretler to the Minister of Interior, 27 Mayıs, 1929, Başbakanlık Cumhuriyet Arşivi (hereafter BCA) 030.10.8.48.6. 
Every child has been born possessing equal rights [müsavî hakka malik olarak]. But some are able to claim their rights, while others cannot. As you see, children who cannot claim their rights are the poor children who are to be protected by child protection organizations. ${ }^{12}$

The 'child question' included reducing high infant and child mortality rates, improving child health, addressing the plight of orphaned, abandoned or homeless children, enabling a greater number of children to attend primary school, and preventing the most exploitative forms of child labor. The child question became a potent site to both project the potential of the nation-state through reform and to challenge the efficacy of the new government's approach to nation-state building. ${ }^{13}$

\section{The Children's Protection Society as 'Stand-in' for the State}

In the late Ottoman period, a group of doctors, political leaders and other professionals established the Children's Protection Society [Himaye-i Etfal Cemiyeti / Çocuk Esirgeme Kurumu], initially as a humanitarian effort to provide relief to children orphaned or displaced by war. ${ }^{14}$ Led in the 1920 - 30 by Dr Mehmet Fuat Umay, a doctor and parliamentarian, the CPS developed a network of branches throughout the country. It gradually expanded its charge from the initial aims of providing humanitarian relief to children to one that worked to secure the welfare of children and their mothers. ${ }^{15}$ In core areas like Istanbul and Ankara, the CPS provided some on-site housing for orphans. The CPS also intensified campaigns to provide safe milk for infants, pre-natal and post-natal medical check-ups for mothers, well-baby check-ups, vaccinations and bathing facilities to promote 'hygienic' mothering practices with young infants and children as well as clothing and hot lunches for school children. One of the CPS's lasting legacies in the early Republic was its efforts to publish popular and professional serials advancing children's well-being and promoting 'modern' child-rearing practices. Its publications also served the purpose of highlighting the efforts of the CPS to secure child welfare, not only for

\footnotetext{
12 Halkacı, Çocukları Esirgemenin Modern Tekniği, 15.

13 For fuller treatment of the socio-economic conditions that informed debates over child poverty and child welfare, see Libal, "The Child Question."

14 Libal, "The Children's Protection Society."

15 Veysi Akın, Bir Devrin Cemiyet Adamı Doktor Fuad Umay (1885-1963) (Ankara: Atatürk Kültür, Dil ve Tarih Yüksek Kurumu, Atatürk Araştırma Merkezi, 200o).
} 
Turkey's most marginalized children, but also that of children in middle-class households. ${ }^{16}$

The CPS recognized an overwhelming need for children's protection on all fronts and focused, in particular, on high rates of infant mortality that persisted throughout Turkey. Dr Umay, like other doctors concerned with child health, thought that only through curbing the numbers of babies lost in the first few years of life could the Turkish state's goals for significant population growth be met. Dr Şemsettin Dora, a pediatrician at the State Hospital (Memleket Hastanesi) associated 'population politics' with 'child politics,' asserting that "the child is the country's most precious treasure; to protect the child is to protect the country."17 Dr Suad Yilmaz similarly emphasized the 'national duty' to raise children, underscoring that providing pre- and postnatal care to women and infants would strengthen the country, ${ }^{18}$ while Dr Halkacı underscored that child protection was directly connected to the country's economic growth and well-being. ${ }^{19}$ Or, as Alemdaroğlu asserts of other leaders in public health and hygiene initiatives: "bodies were the principal and most profitable capital of a nation-state." 20

In order to promote the reduction of infant mortality rates, the CPS wrote and disseminated educational materials on child health, child care and nutrition. Leaders of the organization regarded training [terbiye] and public education [propaganda] as crucial to fostering modern principles of child welfare, which were grounded in the young child's life course (from securing women's health during pregnancy through early educational years). ${ }^{21} \mathrm{~A}$ July 1931 issue of Gürbüz Türk Çocuğu included an article on a 'school for mothers' in Vienna. ${ }^{22}$ The subtitle of the article noted that "regardless of class" all mothers are taught child rearing. The authors of the article highlighted the value of intensive

16 The CPS sponsored a variety of publications, including a series of books for children in translation published by Sabiha Zekeriya Sertel and Zekeriya Sertel through Resimli Ay Matbaası. In the late 1920s through the 1930s the CPS also sponsored the serial Gürbüz Türk Çocuğu [The Robust Turkish Child], which aimed at times for a public literate elite and during certain periods seemed more focused on health and social service professionals. The CPS also sponsored more popular publications like Çocuk Haftası [Child's Week].

17 Şemsettin Dora, "Yeni Rejimde Çocuğun Ehemmiyet ve Kıymeti," [The Importance and Value of the Child in the New Regime], Uludağ, 18, 1938, 45, 47.

18 Suad Yılmaz, "Çocuk Yetiştirmek Bugün Bir Vatan Borcudur," (Raising Children Today Is a National Duty), Cumhuriyet, 17 June, 1937, 4.

19 Halkacı, Çocukları Esirgemenin Modern Tekniği, 7.

20 Alemdaroğlu, "Politics of the Body," 70.

21 Halkacı, Çocukları Esirgemenin Modern Tekniği, 5-9.

22 “Anneler Mektebinde” [At Mothers' School], Gürbüz Türk Çocuğu, 58, July, 1931, 8-10. 
classes given on topics concerning spiritual and physical education, including how to appropriately nourish infants. Photos accompanying the article show nurses demonstrating to mothers how to weigh their baby and demonstrating how to appropriately swaddle infants. CPS officials also published posters, pamphlets and monthly magazines and broadcast radio addresses on childhealth and child-care techniques in an effort to reach greater numbers of Turkish mothers and families.

A substantial proportion of articles in CPS publications highlighted the necessity of developing institutions to address large numbers of children who did not have families to care for them. Often such work drew heavily on the writings of European specialists in translation. Such articles showed that the child question was not confined to Turkey, but also included social welfare strategies developed to address children dislocated from families in European countries such as Germany or the United Kingdom. An article in Gürbüz Türk Çocuğu in 1931 drew upon experiences of addressing 'abandoned' children in Berlin, underscoring the value of adoption rather than the long-term institutionalization of children in orphanages. The article stressed the importance of fully accepting adopted children within the household through giving the child the family's name and the rights that should be accorded to the child as a family member. ${ }^{23}$

While CPS literature must be understood as engaging global awareness of child welfare programs and norms, serial publications of the CPS, its regional reports and annual meetings also contributed to a sense of the 'national' spread of the organization. Annual yearbooks published in 1929 and 1930 included photos representing the work of local CPS chapters. Gürbüz Türk Çocuğu also included such photos, paired with listings of the leadership in a given branch. Leaders were often elites from the community in question, such as the Polatlı Branch's head, Saim Bey, who was also a manager for İş Bank. ${ }^{24}$ Delegates were as often doctors, head teachers or civil servants within the local or provincial government. And, such publications inevitably included photographic representations of the most celebrated period of the year in terms of advancing child welfare, 23 Nisan Bayramı (April 23, the foundation day of the Turkish National Assembly and also the Children's Holiday [Çocuk Bayramı]).

23 "Yeni Anne ve Baba Arayan Yavrular" [Little Ones Looking for New Mothers and Fathers], Gürbüz Türk Çocuğu, 58, Temmuz 1931, 11-13. Adoption did not emerge as a widespread, culturally acceptable practice; however, evlatık, or informal 'adoption' practices, were widespread, particularly with girls.

24 See, for example, "Himayei Etfal Haberleri" [News of Children's Protection (Society)], Gürbüz Türk Çocuğu 58, July 1931, 22. 
Impeccably clad school children lined streets, school yards or the entrances to municipal buildings in locales across the country. Children selected as model "robust children" were displayed to readers of the CPS serial publications and highlighted in local and national newspapers. ${ }^{25}$

\section{Defining a Role for the State in Securing the Rights of Children}

Debates on child welfare during the 1920 and 1930 soint to childhood as a vehicle for talking about modernization, nation-state building and processes of social transformation. These larger processes were in some ways more open to debate through the 'child question' than through other issues, such as the rights of workers, single-party rule and the repression of those who supported a greater role for Islam in official and popular domains. For reformers, the broad social terrain encompassed by a notion of child welfare and children's protection became increasingly politicized. The plight of children as portrayed in the media and witnessed by sometimes competing elites became one form of political capital exercised in debates about how to construct a modern Turkish society and strong nation-state.

Large numbers of elementary-school age children in urban Istanbul worked in and outside of their homes to contribute to family income (or to survive on their own). According to newspapers and professional journals of the day, many infants, toddlers and children of school age did not receive adequate nutrition and an undetermined (yet large) number of these children were chronically hungry. In the early 1930 s campaigns were led by the Turkish Red Crescent Society to feed elementary school children who were chronically hungry. Branches of the TRCS in Istanbul initiated a campaign to feed such poor children several times a week. In 1929, one of the Ministry of Education's health inspectors asserted that a 5 -kuruş donation would provide funds for one meal to a needy child. This child would then be able to have bread and cheese at lunch, as well as under some programs a 'hot lunch' with variations of soup, bread, cheese and helva. ${ }^{26}$ In 1934 the issue resurfaced again and the Minister of Interior, Sü̈krü Kaya, paid a visit to Istanbul in part to address growing concern over the issue of child hunger. ${ }^{27}$ By 1937 he estimated the number of hungry school children had grown from 7,000 in 1934 to close to 15,000. As a part of

\footnotetext{
$25 \quad$ For more on this see, Libal, "The Robust Turkish Child."

26 "Fakir Çocuklara Sicak Yemek Tevzi Edilmez Mi?" Cumhuriyet, January 15, 1929.

27 Neşet Halil Atay, "İstanbul İlk Mekterplerindeki 700o Çocuk," [Istanbul's 7,00o Primary School Children], Gürbüz Türk Çocuğu 97 (1934), 3-7.
} 
an effort to better prepare private and official organizations to provide hot meals to children, officials in the Ministry of Education in Istanbul worked with the CPS, TRCS and local social assistance wings of People's Houses [Halk Evleri] and branches of the Republican People's Party to create a manual instructing them on how best to carry out their work. ${ }^{28}$

Throughout the 1930s social reformers called for the formation of a social institution embedded within the state that could adequately address the needs of the Republic's children. ${ }^{29}$ Greater resources from the government were required immediately to address inadequacies in securing child welfare in all institutions, including branches of the Children's Protection Society and Red Crescent Society, state-run orphanages, and boarding houses attached to schools, which combined were unable to even remotely meet the needs of the urban poor. Addressing child poverty in towns and rural areas, particularly in the 'Eastern' regions, was an even more distant prospect. ${ }^{30}$

A series of government documents from 1936 to 1939 reveals the contours of governmental debate over how to address 'abandoned' children [metruk çocuklar], meaning children without families who could care for them, in towns and cities. Dr Fuat Umay and other CPS representatives raised concerns with officials at the highest levels of government about how to address the needs of orphaned and 'abandoned' children once they turned six years old. ${ }^{31}$ Dr Umay argued that the government bore the responsibility for providing protection to such children formerly in CPS care or within state-run orphanages. ${ }^{32}$ This was ostensibly the time when children would begin attending schools, but boarding schools and day schools were not adequately established or funded by municipalities and the national government to provide spaces for a great number of

28 See, e.g., "Yoksul Çocuklar: İlk Mekteb Talebelerine Nasıl Yardım Edilecek?" [Poor Children: How are Elementary School Students to be Helped?], Cumhuriyet, January 7, 1937, 7; "Yoksul Talebeye Yapılacak Yardım" [Assistance to Be Given to Poor Students], Cumhuriyet, January 10, 1937, 2.

29 Libal, "The Child Question," 268.

$30 \quad$ Bahri Turgud Okaygün, "Şarkî Anadoluda Köyler ve Köylüler: Şark Köylerinde Çocuk Meselesi" [Villages and Villagers in Eastern Anatolia: The Child Question in Eastern Villages], Cumhuriyet, July 12, 1937, 2.

31 Correspondence from the Head of the Malatya Children's Protection Society, Sabri Akalın, to Prime Minister İsmet İnönü, August 7, 1937, BCA 030.10.178.234.1. The Malatya CPs head requested financial support from the national government to help address the needs of street children, who he portrayed as gathering in Malatya from various counties [ilçe] after finishing their education.

32 Correspondence from the Head of the Children's Protection Society, Dr Fuat Umay, to Prime Minister Celâl Bayar, March 25, 1938, BCA 030.10.178.234.1. 
children. The CPS head framed the social problem as a 'painful inheritance' from the Ottoman era, saying that with each day that the CPS carried out its efforts conditions were more serious.

In the same series of documents, the Minister of Health and Welfare, Dr Ahmet Hulusi Alataş, noted that the CPS was a private philanthropic organization and for this reason, children of school age should no longer be under CPS care. ${ }^{33}$ In late 1937 the Minister of Health and Social Welfare acknowledged that elementary-aged children without families should be the responsibility of the state broadly, with municipalities and the Ministry of Education bearing obligations to support the inclusion of such children within urban 'boarding schools.' By mid-1939, with the apparent closure of a number of urban boarding schools, the same minister proposed that by the time children reached an age where they could reasonably work (12 years), they should begin jobs at state-owned factories and other workplaces. ${ }^{34}$ What is striking in the documents is the struggle over which part of the national government would ultimately bear responsibility for the welfare of poor children who had little or no family supports once they became too old for CPS care..$^{35}$ The documentation, however, underscores that leaders recognized a role for government in securing child welfare, even as they struggled with the overwhelming scope of the 'child question.'

Such debates were carried out more visibly in print media, beginning in the earliest years of the Republic. Shortly after returning to Turkey from university studies in social work at the New York School of Social Work, Sabiha Zekeriya (Sertel) called for a "children's crusade" [çocuk cihadı] in the influential Resimli $A y .{ }^{36}$ As James Ryan notes, this was a "clear reference to the 'Children's Crusade'

33 Correspondence from Minister of Health and Social Welfare Dr Ahmet Hulusi Alataş to the Prime Ministry, December 14, 1937, BCA 030.10.178.234.1.

34 Correspondence from the Minister of Health and Social Welfare Dr Ahmet Hulusi Alataş to the Prime Ministry, June 24, 1939, BCA 030.10.178.234.1.

35 Education Minister Hasan Ali Yücel asserted that local Istanbul control of homes to protect orphaned children between 1933-1939 had not been well organized or administered, and thus the operation of such facilities would come under the oversight of the Education Ministry. The minister noted that private (philanthropic) administration and municipal budgetary support had failed to successfully address the needs of these children. Thus the national government was obligated to step in and take control. Correspondence from Minister of Education Hasan Ali Yücel to the Prime Ministry, September 26, 1940, BCA 030.10.174.201.6.

36 I owe these insights to James Ryan, who included analysis of Sabiha Zekeriya Sertel's child welfare advocacy in his unpublished paper, "A Revolution In-Between: M. Zekeriya and 
march from the Kensington neighborhood in Philadelphia to Oyster Bay, New York organized by Mother Jones in 1903." Sabiha Sertel, drawing upon her understanding of the Children's Aid Society and the work of Mary Harris Jones ("Mother Jones") was especially drawn to the harsh circumstances of orphans in Turkey's cities.

Similarly, in an essay entitled "Our Children," the writer and educator Hifzı Tevfik (Gönensay) asserted that caring for orphaned or abandoned children was one of the key issues to be addressed by the state. For Tevfik, the child question could only be solved by "creating an organization addressing the whole country." He explained:

For this, definite and fundamental steps must be taken. Despite the work that Himaye-i Etfal has done [...] it is not sufficient. From day to day the number of children who are vanishing because of neglect is increasing beyond all predictions, despite the wonderful services provided by Himaye-i Etfal. ${ }^{37}$

Other prominent figures, such as Yunus Nadi (Abalığlu), editor and chief of the leading Istanbul newspaper, Cumhuriyet, exhorted readers to consider the problem of the child as a key national problem, claiming that it would signify Turkey's 'civilization' and modernity if everyone concerned themselves with protecting children. Yunus Nadi's writings on the importance of the child for the future of the Republic resonated with the most strident Kemalist declarations on the centrality of the child. His stance was closely linked to nationalist, eugenicist concerns, with the health of the Turkish populace as a signifier of the health of the Turkish race and nation-state: ${ }^{38}$ " $[\mathrm{B}] \mathrm{y}$ showing concern not only with our own children, but also the children of the entire country, we provide proof that our society is a strong one."39

Sabiha Sertel as Pro-western Anti-Kemalists, 1919-1924." Sabiha and M. Zekeriya Sertel co-founded Resimli Ay with Yunus Nadi. It became an important progressive publication, alongside sister publications Resimli Hafta and Resimli Perşembe.

37 Hıfzı Tevfik, "Çocuğumuz" [Our Children], Çocuk Haftası 1, 1929, 89.

38 See also Alemdaroğlu, "Politics of the Body"; Sanem Güvenç Salgırll, "Eugenics for the Doctors: Medicine and Social Control in 1930s Turkey," Journal of the History of Medicine and Allied Sciences, 66 (3), 2010, 281-312.

39 Yunus Nadi (Abalığlu), "Küçüklerimizin Çok Büyük Bir Meselesi” [Our Little Ones' Very: Large Problem], Cumhuriyet, April 25, 1936. 


\section{A Declaration on the Rights of Children in Turkey}

In April 1929, in recognition of 'National Sovereignty and Children's Day' held on 23 Nisan (April 23) and Children's Week, Sabiha Zekeriya Sertel issued a Declaration of Children's Rights in a leading child welfare publication. ${ }^{40} \mathrm{Her}$ list of 'rights' that should exist for all Turkish children was illustrative of a genre of declarations emerging in the 1920s and 1930s in Europe and other parts of the world, that called upon the state to take a leading role in children's welfare. It can be read as a more expansive (albeit local) call for securing children's rights than the earlier Geneva Declaration of the Rights of Children adopted by the League of Nations in 1924 and discussed below. ${ }^{41}$

The Declaration was notable because of its length, specificity and the emotive linking of religious and cultural referents to that of the new nation-state (which was avowedly secular). Through the imagined voices of children (using first person plural), the document expresses the "wants" of children and approximates framing such wants as 'rights claims' on the state:

We, this generation's children of Future Turkey, request from the Children's Protection Society and from the larger Turkish society, the following:

1. We, the children who grow at the breasts of mothers with tuberculosis, want food, air, and life.

2. We, the children who have engorged bellies on our skinny legs that are bigger than our sins and who await the Angel of Death in our sleep, we who are neglected and forgotten, want the means of healthy living and to stand up straight.

3. We, who are rented to death and disease ${ }^{42}$ by extreme poverty and who are hungry want bread, bread, bread.

4. We, who beg naked on piles of snow, day and night, manipulating your sense of compassion don't want your charity [...].

5. We, the children who are deprived because of a lack of human compassion, perform heavy labor, and are exploited in order to make a living, want laws that will protect us.

40 Kathryn Libal, "Sabiha Zekeriya Sertel: Turkish Feminist, Organizer, and Journalist," Affilia:Journal of Women and Social Work, 27 (3), 2012, 328-337.

41 The full text is available at http://www.un-documents.net/gdrc1924.htm.

42 "Rented to death" in this context means having another older child or adult control the labor of children, impressing them into begging, stealing or performing heavy labor, such as hauling objects on their backs. A common image of poor beggar children was that they were organized in bands and impelled to use childlike ways to garner donations. 
$[\ldots]$

11. We, the children who have been sacrificed to the Angel of Death before we were even two years old, want this relentless flow of death to be stopped. We want you to mobilize against the attacks of the Angel of Death just as you fight against the enemies [of the nation] ${ }^{43}$

In this Declaration, Sabiha Zekeriya employs a modernist lexicon of disenfranchisement - focusing on deprivation, child labor, exploitation, endemic poverty and the need for reforms that encompass more than individual acts of charity. Also, she invokes emotive notions of sacrifice and the presence of Azrael, the Angel of Death, who must be defeated just as would-be colonizers were repelled a decade earlier. The declaration ended with a final pronouncement:

WE-The Turkish children deprived of life, food, health care, and development and whose stomachs are empty: We want you to find a solution for our problems in this Children's Week that you have created for us. We came to you with these problems and our handicaps. We don't only want your nurturance. We want equality, nutrition, development, and education that are the right of every human child. We want new laws and a social organization that will provide us with the rights and the life that we lack.

Such advocacy for laws and a 'social organization' to provide children with legal rights and basic assurances of welfare are found throughout newspapers, weekly publications and professional journals, and in transcripts of radio addresses from the 1930s. A growing cadre of 'helping' professionals, educators, political leaders and journalists all invoked the idea that children had rights to be secured by larger national projects, whether enacted by the state directly or implemented through quasi-state institutions such as the Children's Protection Society. Their modernist vision supported a greater investment in state institutions to secure children's and the broader population's well-being. This endeavor entailed a shift to a more extensive, bureaucratized form of child welfare that combined local initiative and control with greater levels of national monitoring and agenda setting. Throughout this era, however, the actual reach of the CPS and other state-funded efforts for orphanages, boarding schools and health clinics remained limited in scope. ${ }^{44}$

43 Sabiha Zekeriya, "Biz...," Çocuk Haftası 1, 1929, 44.

44 Libal, "The Children's Protection Society." 
Sabiha Zekeriya Sertel's Declaration on behalf of Turkish children was related to an emerging international discourse on children's rights and the responsibility of states to assure that children both survived and thrived into adulthood. ${ }^{45}$ 'Children's rights' in the aftermath of the First World War were regarded as a leading social problem and the Geneva Declaration addressed sentiments being expressed at national and international levels about developmentalist needs to protect children who were orphaned, displaced from homes, malnourished and unable to access education. In 1924, The Geneva Declaration on the Rights of the Child had called for "men and women of all nations" to "accept it as their duty" that

- The child must be given the means requisite for its normal development, both materially and spiritually;

- The child that is hungry must be fed; the child that is sick must be nursed; the child that is backward must be helped; the delinquent child must be reclaimed; and the orphan and waif must be sheltered and succored. ${ }^{46}$

Moreover, children's needs were to be prioritized during "times of distress" and children should be assured of being able to earn a livelihood without exploitation. Its five articles concluded with the assertion that "[ $t]$ he child must be brought up in the consciousness that its talents must be devoted to the service of fellow men." The Geneva Declaration foreshadowed future international declarations and treaties that would emphasize children's rights to economic and social provisions commensurate with their capacities as children within society and their rights to be free of exploitative forms of labor that might endanger their health and development.

Sertel's Declaration was longer than the Geneva Declaration, and it elaborates on what would come to be known as children's economic and social rights - their rights first and foremost to life, health, nutrition, housing and education, and to be free of exploitative forms of labor. ${ }^{47}$ The document is

45 Lara Bolzman, "The Advent of Child Rights on the International Scene and the Role of the Save the Children International Union 1920-45," Refugee Survey Quarterly 27 (4), 2009, 26-36.

46 http://www.un-documents.net/gdrc1924.htm.

47 The focus on children, their physical and mental health, strength, cleanliness and intelligence sharpened in a climate of extreme nationalisms during the interwar years. In Turkey during the 1930s the Ministry of Education became increasingly preoccupied with physical education as a way to strengthen youth. Exercises for both boys and girls blended physical training with regimentation and militaristic routines that were common in other parts of Europe. See Alemdaroğlu, "Politics of the Body." 
remarkable in its specificity and direct call for the establishment of a social welfare system that could assure these rights (wants) as a matter of state obligation. Printed in an official publication of the Children's Protection Society during national celebrations focusing on Turkish children during 'Children's Week, Sertel's document ostensibly had the support of cPs leadership. Sertel's familiarity with child welfare institutions and movements for children's rights in the United States shaped her call: she was deeply influenced by the three years she had spent in New York and by her travels with the CPS leader, Dr Fuad Umay, in the United States to raise funds for the organization. ${ }^{48}$ This work must also be understood as being a part of state-making processes elsewhere that sought to incorporate and transform charitable efforts on behalf of the poor into laws, policies and programs that addressed the poor as a matter of modern state policy.

\section{Exhibiting Unequal Childhoods through Reportage and Satire}

The fact that neither the state nor local philanthropic organizations were able to meet the basic needs of large numbers of children living in poverty was highlighted in the reportage of widely published journalists such as Sertel and Suad Derviş. ${ }^{49}$ Before widespread crackdowns on socialist and communist writers in the late 1930s and early 1940s, Sertel's and Derviş's columns were commonly published in Cumhuriyet and Tan and were reprinted in CPS journals. Derviş, an active member of the banned Turkish Communist Party during the 1930 and 1940s, often wrote articles based on interviews with poor widows with children, working mothers and orphaned or abandoned children. By reporting the issues close to the hearts of working women and children, Derviş challenged the state and other organizations perceived to be closely aligned with the state.

\footnotetext{
48 Libal, "Sabiha Zekeriya Sertel."

49 Derviş, who studied in Berlin in 1919-1920, published her first novel, Kara Kitap, in Istanbul in 1920. She published more than 10 novels from 1920-1932 and worked simultaneously as a freelance journalist. Because of her fluency in French and German, she covered the Lausanne Conference in 1922-1923, thus securing her reputation within the journalistic arena in early Republican Turkey. See Fatmagül Berktay, "Derviş, Suat (Saadet Baraner) (1905-1972)," in Francisca de Haan, Krassimira Daskalova and Anna Loutfi (eds), A Biographical Dictionary of Women's Movements and Feminisms: Central, Eastern, and Southeastern Europe, 19th and 2oth Centuries (Budapest: Central European Press, 2006), $109-113$.
} 
Sabiha Zekeriya asserted that many historically specific social concerns must be addressed as part of the child question. In an article for Cumhuriyet in which she explained the relevance of Children's Week, she provided a lengthy list outlining the parameters of this problem. The list illustrates the symptoms of persistent poverty and the fracturing of family and local communities that were widespread during post-war reconstruction and the depression years. Sabiha Zekeriya's account included the following catalog of child-types who were produced in a society that had yet to develop a comprehensive welfare program:

orphaned children, poor children with parents, sick children, street children, child thieves, girls who have been adopted into families, children deprived of toys and fresh air, children forced into heavy labor from a young age, children with tuberculosis, beggar children, mentally handicapped children, illiterate children, children of working mothers, children raised in dirty and immoral conditions, homeless children who grow up on the streets, village children and schools, children raised by ignorant mothers, and child prostitution..$^{50}$

Such a classification of social categories of children (largely as problems to be addressed) underscores the dominant view among social reformers that the state had a significant role to play in child welfare. Orphans and poor children led the list, as children deprived of an imagined "ideal childhood" filled with toys, education and a mother's nurturance. The notions of "children raised in dirty and immoral conditions" and child prostitution were tied to a host of anxieties over child sexuality, morality and social control.

Commentaries highlighting children's experience of social inequality were widely published in the mid-1920s and 1930 s and reflected the politicization of child welfare and children's rights in the early Republic. The weekly serial Akbaba published satirical cartoons that visually underscored the gap between wealthy and poor in (Istanbulite) Turkish society, often focusing on children or the elderly. In one instance, the cartoonist Orhan Ural portrayed a father dressed in top hat and tuxedo walking down the street with his hand in his

5o Sabiha Zekeriya added that other problems have yet to be named, and that the CPs had embarked upon Children's Week to raise national awareness of these issues. She outlined various standpoints from which the children's problem can be considered, including diplomatic/military, pedagogical and sociological views. For each, the problem is tied to larger issues of "population" [nüfus işi]. See Sabiha Zekeriya (Sertel), "Çocuk Haftasının Gayesi Nedir" [What is the Purpose of Children's Week?], Cumhuriyet, April 25, 1929, 3. 
daughter's. ${ }^{51}$ The daughter was dressed in stylized 'traditional' Turkish attire donned for a 'costume ball.' A boy was depicted on the same street glancing back at the father-daughter pair. The child wore tattered clothes and a rag tied to his head. The daughter asked her father, "Baba, is this child also going to the costume ball?" Such cartoons condensed a critique of class difference in exaggerated portrayals of dress and body size and brief, incisive commentary. Justifications of such difference were intended to appear flimsy— to heighten a sense of the injustice of a society which tolerated vastly different opportunities and outcomes for children.

Other instances were critical of the gap between the oft-cited connection between the nation and child in public and political discourse and the reality of most children's lives. One cartoon published on the front page of Cumhuriyet on Children's Day 1935 satirizes the joyous celebration of school children marching down the street. The reader viewed Children's Day through the perspective of a child-porter [hamal] carrying a basket filled with vegetables on his back. Clothes tattered, wearing worn-out slippers, he waves to a parade of happy children marching together. The child-porter calls out: "Long may you live! This is our holiday too!" The school children on the other hand bear placards with slogans like, "We want toys!" and "We want to play!" In this image, the cartoonist, Ratil Burak, represents for the reader the contradiction between an idealized childhood celebrated on Children's Day and the more commonly encountered child of limited means in the new Republic.

Such commentary undermined the official Republican ideology that Turkey was a classless, relatively homogenous society, in which people related to one another on solidarist connections by occupation (peasant/farmer, factory worker, greengrocer, etc.). Leftist journalists writing on child welfare utilized images of poor, undernourished or abandoned children to challenge the ideology. These writers and artists underscored in literary and visual terms the plight of poor children. Through their invocation of children excluded from the national imaginary of robust childhood, health and future strength, leftist elites called readers' attention to stratification along lines of economic, political and social difference. ${ }^{52}$

$51 \quad$ Published in Akbaba, 13 (100), 1938, 15.

$5^{2}$ William Hale writes of the mid-1930s Republican stance on labor unions:

The official rationale for the banning of strikes and trade unions under the 1936 Labour Law was part of the RPP's (Republican People's Party) 'populist' philosophythat Turkey was not a class-divided society and that the worker's interests were wellprotected by a paternalistic state. The point was hammered home by an article of the Societies Law, passed in 1938, which forbade the formation of 'associations based [...] 
Public discourse on the nature of the child question and possible avenues to redress poverty and other related problems were constituted through vocabularies and practices that acknowledged and reified distinctions of privilege, stratification and hierarchy in the 'new Turkey.' Newspaper articles, editorials and memoirs used vocabularies of difference that underscored the embeddedness of social and economic hierarchies. In an article on the Turkish woman after the War of Independence, the author refers to those of the "high class" [yüksek tabaka], "families of middling conditions" [orta halli aileler], "artistic and merchant classes" [sanat ve ticaret sinıfları] and the "little classes" [küçük sinuflar]. The diminutive of "little" for the latter category euphemized the position of those at the lower rungs of the socioeconomic order. ${ }^{53}$ In a different article, on the development of child protection in Turkey and the world, M. Celal Bey cites distinctions between children of the "working class" [amele sinuflar] and "children of families with middling means" [mütevasıt ailelerin çocukları] ${ }^{54}$ Meanwhile, other writers characterized difference in terms of the binary 'rich' and 'poor.' In the early 1920s, İsmail Hakkı (Baltacıoğlu) took to task those elites who felt educating orphans towards "intellectual professions" [fikir meslekleri] was a waste of resources. His essay was reprinted in a collection for educators in $1930 .{ }^{55}$ İsmail Hakkı ridiculed those who felt that educating the poor was misguided. He takes on the voice of one such critic:

You accustom them (orphans) to comfort, however, in their own families they do not have a place to sleep. You have them benefit from the possibilities of wealth, however they are poor children! In sum, you teachers who work in orphanages, you are not raising these children in accordance with the (reality of) their future lives that will bring poverty. You are not taking into account their families, past, and social class. You are ruining them. ${ }^{56}$

From this position, children were predestined to replicate the class position of their parents, and accustoming them to comfort 'ruined' their ability to

on class.' (William Hale, The Political and Economic Development of Modern Turkey [London: Croom Helm, 1981], 65-66.)

53 "Bugünkü Türk Kadını: İstiklâl Harbindeki Yararlık ve Cesaretile Temayüz Etmiştir" [Today's Turkish Woman: She Distinguished Herself through Bravery and Service during the Independence War], Cumhuriyet, July 25, 1934, 7.

54 M. Celal, "Çocuk Himayesinin Tekâmülü" [The Development of Child Protection / Child Welfare], Çocuk Haftası 1, 1929, 78.

55 İsmail Hakkı Baltacıoğlu, "Yetim de Bir İnsandır!" [An Orphan is a Person Too!], in Mürebbilere [For Teachers] (Istanbul: Sühulet Kütüphanesi, 1932), 184-188.

$5^{6}$ Baltacıŏlu, "Yetim de Bir İnsandır!" 184. 
tolerate hardship and want. İsmail Hakkı's account underscores the politics of socio-economic differentiation in the early Republic. By the mid-1930s, the Republican government formalized its position that Turkey was a classless society, though this largely masked in rhetoric the playing out of difference, privilege and continuation of a divide between rich and poor.

For writers such as Sabiha Zekeriya, in the child resided a promise of the erasure of such difference and the realization of an ideal form of citizenship in which all children enjoyed good health, proper nutrition and the benefits of education:

The infant resting in the cradle neither has religion, race, nor class. Infants in a golden cradle and a cardboard cradle are the same. In this country no one can know which one is more useful. By organizing all the social power/strength, we must provide children with as much equality as the rights of society will allow. ${ }^{57}$

Sabiha Zekeriya's call to equality was shared by others. Hıfzı Tevfik's concerns for child welfare reprinted in Çocuk Haftası in 1929 also referenced the contrast between a child of privilege and of mean circumstances. In the author's estimation, children, regardless of whether they were rich or poor, deserved the attention of the nation's leaders:

I see that child whose golden hair frames the white face and deep blue eyes that he borrowed from the skies. Sometimes I see this child happily running in the wide salon with polished hardwood floors and heavy velour curtains. Sometimes I also see a child squatting in a corner of a building with ruined marble, broken and hungry, sadly thinking. These two children are the inheritors of the same blood and mind and I love them equally. 58

Through education and good parenting these differences would fade in the new Republic. For Hıfzı Tevfik, the gulf between the experiences of rich and poor stemmed from historical circumstances in the late Ottoman Empire. The natural course of modernization and introducing mass education to all citizens would level such differences and create a universal, ideal Turkish childhood in which children balanced education and pleasure, were in good health and had plenty to eat and wear.

57 Zekeriya (Sertel), "Cocuk Haftasının Gayesi Nedir?.”

$5^{8}$ Hıfzı Tevfik, “Çocuklarımız” [Our Children], Çocuk Haftası 1, 1929, 88-89. 
This vision was more confident than that of socialist activists. In Sabiha Zekeriya's estimation, for example, the Republican approach to the 'child question' and the continual invocation of children as the foundation of Turkey's future were little more than masks veiling the 'thinness' of its ideology on populism and goodwill towards 'the people.' Feroz Ahmad has framed the distinction between those holding administrative power and 'the people' in a way that underscores the object of leftist dissent and hints at more popular discontent as well:

[A] gulf was created between the rulers and the ruled who found they had less in common with the new elite which seemed to live in a world totally different from their own; the elite dressed differently and spoke a language they could not understand. And yet the rulers claimed to be populist. This alienation continued to grow throughout the 1930s and was aggravated with the death of the charismatic Ataturk. ${ }^{59}$

Difference could be marked in terms of dress, occupation, level of education, language and accent, home and neighborhood, and whether one was 'of the city' or a villager. Reformist projects accelerated and punctuated binary classifications so familiar in other national contexts of the same era, including: urban/rural, literate/illiterate, civil servant / manual laborer and progressive/ backward, among others. In the realm of childhood, celebrating robust children, the accomplishments of school children, even giving sweets to orphans or allowing children to ride public transport toll-free for the day did as much to mark privilege in the new Turkey as to create new practices and beliefs in the name of modernity.

\section{Conclusion}

Though social stratification and economic inequality were certainly 'real' in the early Republic, part of the reason 'the people' participated (or at least tolerated) the elite-driven reform had to do with their aspirations towards bettering their lives - of being 'modern.' One could hope that modernization would bring improvements in health, education and transportation, and access to goods that would make one's life more comfortable. Everyday encounters with children on streets, in factories, fields and schools underscored that Turkey was a country of great inequality. According to Kemalist social reformers, those

Ahmad, Making of Modern Turkey, 92. 
disparities would cease to exist once Turkey had adequately modernized industry and agricultural practices, implemented universal educational programs, and expanded health services for the populace.

Seth Koven comments that an irony of the history of liberal (or liberalizing) nation states resides in the fact that "the exploitation of the political capital" generated by the question of child poverty has been "grotesquely incommensurate with the actual resources devoted to meeting children's needs." ${ }^{60}$ Ten years after the founding of the Republic, the Turkish government consistently allocated only a small proportion of its budget to issues of health and welfare and a slightly larger proportion to education and justice. On the other hand, allocations for internal security and international defense-the military, jandarme and police - commanded the largest percentage of annual state budgets. ${ }^{61}$ One might say that this could only be expected given Turkey's recent emergence as a nation-state at that time and the desire of leaders to secure sovereignty in an uncertain European and international climate. After all, only in retrospect do we know of Turkey's ability to secure its borders and maintain an uneasy neutrality during World War II.

Regardless of claims for 'national defense' or state 'sovereignty', it is difficult to reconcile the disparities in state spending on military and police measures with those resources spent on social programs, and institutionalizing reforms to education, health and welfare in the early Turkish Republic. Social activists, like Sabiha Zekeriya Sertel, Suad Derviş or Dr Fuat Umay, certainly pressured the state through their political activism to take a larger role in securing the basic needs of children and families who lived in poverty. They and other social 'experts' and medical professionals succeeded in getting the 'child question' onto the national agenda, as an important social problem to be addressed by the state. The critical voices of social activists and professional elites who worked with children helped to solidify the sense that the welfare of children should be one of the critical elements addressed in Turkey during the 1920 s and 1930s. In the process they helped to redraw the boundaries of the obligations of the state towards its citizens.

This process of defining boundaries of state obligations towards children was marked in the early Republic by reformers' intention to create a 'modern society.' For these reformers, the success of the project was predicated on 'the people' accepting the legitimacy of the Republican government, following governmental and professional elites' programs for social transformation, and swearing allegiance to a new form of extended community — the nation-state.

6o Seth Koven, personal communication.

61 Libal, "National Futures," 89-90. 
In so doing, they were to look beyond the gulf that was so readily apparent between rich and poor, investing in the state ideology of populism based on notions of social solidarity. In this way, 'the people' would work to better their own lives and the lives of their children, until at some undetermined point in the future a leveling of opportunities - of economic, social and political capital — would occur. Certainly at stake in the debates about the social meaning of poor children who played, begged or worked on the street were larger questions of social and economic transformation. Official denial of class interests, class-based affinities or changing inequalities ideologically masked new ways in which socio-economic difference was constructed in the young Republic.

\section{Bibliography}

\section{Primary}

"Anneler Mektebinde" [At Mothers' School], Gürbüz Türk Çocuğu, 58, July 1931, 8-10. Atay, Neşet Halil, “istanbul İlk Mekterplerindeki 7000 Çocuk," [Istanbul's 7,00o Primary School Children], Gürbüz Türk Çocuğu 97, 1934, 3-7.

Baltacıoğlu, İsmail Hakkı, "Yetim de Bir İnsandır!" [An Orphan is a Person Too!], in Mürebbilere [For Teachers], Istanbul: Sühulet Kütüphanesi, 1932, 184-188.

"Biz Bize Çocuklarımız," Cumhuriyet, August 28, 1935, 5.

"Bugünkü Türk Kadını: İstiklâl Harbindeki Yararlık ve Cesaretile Temayüz Etmiştir" [Today's Turkish Woman: She Distinguished Herself through Bravery and Service during the Independence War], Cumhuriyet, July 25, 1934, 7.

Celal, M., "Çocuk Himayesinin Tekâmülü" [The Development of Child Protection / Child Welfare], Çocuk Haftası 1, 1929, 78.

Dora, Şemsettin, "Yeni Rejimde Çocuğun Ehemmiyet ve Kıymeti," (The Importance and Value of the Child in the New Regime), Uludağ, 18, 1938, 45, 47.

"Fakir Çocuklara Sıcak Yemek Tevzi Edilmez Mi?" Cumhuriyet, January 15, 1929.

Halkacı, Kutsi, Çocukları Esirgemenin Modern Tekniği [Modern Techniques in the Protection of Children]. Türkiye Çocuk Esirgeme Kurumu İstanbul Merkez Hey'eti Neşriyatı, Sayı 3, İstanbul: Millî Mecmua Basım Evi, 1937, 3.

"Himayei Etfal Haberleri" [News of Children's Protection (Society)], Gürbüz Türk Çocuğu 58, July 1931, 22.

Nadi (Abalıoğlu), Yunis, “Küçüklerimizin Çok Büyük Bir Meselesi” [Our Little Ones' Very: Large Problem], Cumhuriyet, April 25, 1936.

Okaygün, Bahri Turgud "Şarkî Anadoluda Köyler ve Köylüler: Şark Köylerinde Çocuk Meselesi" [Villages and Villagers in Eastern Anatolia: The Child Question in Eastern Villages], Cumhuriyet, July 12, 1937, 2. 
Tevfik, Hıfzı, "Çocuklarımız" [Our children], Çocuk Haftası 1, 1929, 88-89.

"Yeni Anne ve Baba Arayan Yavrular" [Little Ones Looking for New Mothers and Fathers], Gürbüz Türk Çocuğu, 58, July 1931, 11-13.

Yılmaz, Suad, "Çocuk Yetiştirmek Bugün Bir Vatan Borcudur," (Raising Children Today Is a National Duty), Cumhuriyet, 17 Haziran, 1937, 4.

"Yoksul Çocuklar: İlk Mekteb Talebelerine Nasıl Yardım Edilecek?" [Poor Children:

How are Elementary School Students to be Helped?], Cumhuriyet, January 7, 1937, 7 .

"Yoksul Talebeye Yapılacak Yardım" [Assistance to Be Given to Poor Students], Cumhuriyet, January 10, 1937, 2.

Zekeriya (Sertel), Sabiha, "Çocuk Haftasının Gayesi Nedir" [What is the Purpose of Children's Week?], Cumhuriyet, April 25, 1929.

\section{Secondary}

Ahmad, Feroz, The Making of Modern Turkey, London: Routledge, 1993.

Akın, Veysi, Bir Devrin Cemiyet Adamı Doktor Fuad Umay (1885-1963) (Ankara: Atatürk Kültür, Dil ve Tarih Yüksek Kurumu, Atatürk Araştırma Merkezi, 200o).

Alemdaroğlu, Ayça, "Politics of the Body and Eugenic Discourse in Early Republican Turkey," Body and Society, 11 (3), 2005, 68.

Berktay, Fatmagül, "Derviş, Suat (Saadet Baraner) (1905-1972)," in Francisca de Haan, Krassimira Daskalova and Anna Loutfi (eds), A Biographical Dictionary of Women's Movements and Feminisms: Central, Eastern, and Southeastern Europe, 19th and 2oth Centuries, Budapest: Central European Press, 2006, 109-113.

Bolzman, Lara, "The Advent of Child Rights on the International Scene and the Role of the Save the Children International Union 1920-45," Refugee Survey Quarterly 27 (4), 2009, 26-36.

Gencer, Yasemin, "We Are Family: The Child and Modern Nationhood in Early Turkish Republican Cartoons (1923-1928)," Comparative Studies of South Asia, Africa and the Middle East 32 (2), 2012, 295.

Güvenç Salgırl, Sanem, "Eugenics for the Doctors: Medicine and Social Control in 1930s Turkey," Journal of the History of Medicine and Allied Sciences, 66 (3), 2010, 281-312.

Hale, William, The Political and Economic Development of Modern Turkey, London: Croom Helm, 1981.

Libal, Kathryn, “'The Child Question': The Politics of Child Welfare in Early Republican Turkey," in Mine Ener, Michael Bonner and Amy Singer (eds) Poverty and Charity in Middle Eastern Contexts, Albany: State University of New York Press, 2003, 255-272. Libal, Kathryn, "Sabiha Zekeriya Sertel: Turkish Feminist, Organizer, and Journalist," Affilia:Journal of Women and Social Work, 27 (3), 2012, 328-337. 
Libal, Kathryn, “The Children's Protection Society: Nationalizing Child Welfare in Early Republican Turkey," New Perspectives on Turkey 23, 2003, 53-78.

Libal, Kathryn, "The Robust Child: Discourses on Childhood and Modernity in Early Republican Turkey," in Daniel T. Cook (ed.) Symbolic Childhood, New York: Peter Lang, 2002, 109-130.

Maksudyan, Nazan, "Hearing the Voiceless-Seeing the Invisible: Orphans and Destitute Children as Actors of Social, Economic, and Political History in the Late Ottoman Empire," unpublished PhD thesis, Sabancı University, 2008.

Maksudyan, Nazan, "Modernization of Welfare or Further Deprivation? State Provisions for Foundlings in the Late Ottoman Empire," Journal of the History of Childhood and Youth 2 (3), 2009, 361-392.

Maksudyan, Nazan, "Orphans, Cities, and the State: Vocational Orphanages (Islahhanes) and Reform in the Late Ottoman Urban Space," International Journal of Middle East Studies, 43, 2011, 493-511.

Maksudyan, Nazan, Orphans and Destitute Children in the Late Ottoman Empire, Syracuse, NY: University of Syracuse Press, 2014.

Özbek, Nadir, "The Politics of Welfare, Philanthropy, Voluntarism and Legitimacy in the Ottoman Empire, 1876-1918," unpublished PhD thesis, State University of New York, Binghamton, 2001.

Özbek, Nadir, Osmanlı İmparatorluğu'nda Sosyal Devlet, Siyaset, İktidar ve Meşrutiyet, 1876-1914, İstanbul: İletişim Yayınları, 2002.

Özbek, Nadir, "The Politics of Modern Welfare Institutions in the Late Ottoman Empire (1876-1909)," International Journal of Turcologia 3 (5), 2008, 42-62.

Ryan, James, "A Revolution In-Between: M. Zekeriya and Sabiha Sertel as Pro-western Anti-Kemalists, 1919-1924," unpublished paper.

Yllmaz, Hale, Becoming Turkish: Nationalist Reforms and Cultural Negotiations in Early Republican Turkey (1923-1945), Syracuse, NY: Syracuse University Press, 2013. 